\title{
Indigenous Knowledge Systems for development: A critical analysis from Nkayi District, Zimbabwe
}

\author{
Whitehead Zikhali, PhD \\ Senior Lecturer: National University of Science and Technology, \\ Institute of Development Studies (NUST-IDS), Bulawayo, Zimbabwe
}

\begin{abstract}
Local and indigenous knowledge refers to the understandings, skills and philosophies developed by societies with long histories of interaction with their natural surroundings. For rural and indigenous people, local knowledge informs decisionmaking about fundamental aspects of day-to-day life. This knowledge is integral to a cultural complex that also encompasses language, systems of classification, resource use practices, social interactions, ritual and spirituality. These unique ways of knowing are important facets of the world's cultural diversity and provide a foundation for locally-appropriate sustainable development (UNESCO, 2017). This paper argues that development is an end which people in the global south seek in the context of a dynamic environment characterised by contesting systems of power. Basing from evidence in Nkayi, an area in western Zimbabwe, the paper deploys Foucauldian lens to reveal contesting systems of knowledge in rural Zimbabwe. In these communities, community members employ a mix of knowledge systems to attaint their forms of 'development'. The paper reveals that development is not a zero-sum game where the use of western knowledge means complete neglect of indigenous knowledge and vice versa. From the analysis made, the authors recommend that a nuanced appreciation of knowledge structures be made by development practitioners and policymakers prior to either embracing or dismissing them. Even then, it cautions against wholly labelling systems of knowledge either indigenous or western due to the cross-pollination which has transpired over time.
\end{abstract}

Keywords: indigenous knowledge systems, Foucault, local, post-coloniality, human development

\section{INTRODUCTION}

Among a raft of inclusive approaches which are now in the mainstream of development policy and discourse is the use of indigenous knowledge systems as alternatives to the hierarchical, top-down architecture of the development industry. Instead of development from above, it is common to learn of development from below. The suggestion is that participatory and more inclusive approaches yield more sustainable development outcomes. Through such efforts as rapid rural assessments, participatory rural appraisal and the entire development movement in the 1980s, an entire gamut of developmental inclusive lexicon was fashioned. Robert Chambers for instance contributed to the discourse by considering to 'put the last first' (Chambers, 1983). This set off an extensive interest in approaches to save, assist, complement and understand the developing world. In the field of postcolonial studies, Gayatri Spivak recast the experiences and narratives of those in the marginalised global south face. Using the concept of the subaltern, she revealed that even those considered of a lowly caste have a voice and that voice was not entirely devoid of power (Spivak, 1987). In a sense, this perspective resonated with the concept of power in the (re)production of information and knowledge which contemporary philosophers and social scientists such as Levi-Strauss and Michel Foucault have addressed (we refer to Foucault in more detail later on). Briefly, the poor, the weak and the marginalised in the global south had for long failed to have their voices heard 
loud enough in academic platforms due to their lack of capital. One might even add that this shortcoming was a result of deficiencies in political and cultural capital (Bourdieu, Language and Symbolic Power, 1991). Subalternity and the inclusive approaches helped to change this tone, as the poor became more recognised and their perspective included in academic discourses. A slew of approaches has since emerged leading to what Cornwall (2007) identifies as 'buzzwords and fuzzwords'. These include empowerment, pro-poor, inclusive and so forth. It is within this family of words, catchphrases and neologisms that indigenous knowledge systems (IKS) belongs. Although useful in identifying what approach is employed, it is often difficult to identify a strict meaning to these words. What is meant by indigenous? Given the fluidity and transmission of various forms of knowledge, what counts as indigenous knowledge? What are the power structures of knowledge even among indigenous knowledges? These questions are germane to places such as Zimbabwe where there are diverse 'inidgenous' ethnic groups and so an indigenous system is hard to fathom.

'Knowledge is power' as Sibanda (1998) observes in his brief on IKS in Zimbabwe. A brief look at the history and trajectory of development helps illuminate this. As Michel Foucault also observes in the history of mankind, 'in the history of knowledge the notion of human nature seems to me mainly to have played the role of ... designat[ing] certain types of discourse in relation to or in opposition to theology or biology or history' (Rainbow, 1984). Knowledge is therefore subject to negotiation and conflict due to the inherent power lying within it. Human nature disposes us to give value forms to different systems of knowledge be they biology, physics, science or what is loosely termed in this paper as western knowledge and indigenous knowledges. To overcome this disposition is difficult but imagining an approach which eases the differences such systems are deemed to have is not. In a sense, this paper envisions a fusion of various systems of knowledge in order for a common goal or objective -in this case human development- to be attained.

The goal here is not to make a conceptual analysis of IKS within the context of Zimbabwe. Instead, it is to reveal the ways in which knowledge systems intersect, overlap and sometimes clash due to their distribution and effect as structures of power. As a result, the paper lays out experiences fron Nkayi using agriculture practice and food preservation as examples. Knowledge systems employed in agriculture tend to be broadly publicised and en vogue as has been th case with conservation agriculture. Agriculture is therefore useful in assessing publicly accessible shows of power through knowledge. The reference to food preservation is however an attempt to assess the dynamics between indigenous and 'western' knowledge in intimate/private spaces. In adopting such an approach, a comparison can be made of how communities deal with various knowledge systems and (re)produce change.

The following section presents a historical portrait of Zimbabwe's post-independence development story. It is succeeded by a discussion of systems of knwledge and power relying heavily on Pierre Bourdieu and Michel Foucault's works. Thereafter, an outline of the research methodology is laid out. A presentation of findings from a study site in Zimbabwe is made before cnclusions and recommendations are presented.

\section{SEEKING DEVELOPMENT: A HISTORICAL PERSPECTIVE ON ZIMBABWE}

Having attained political freedom in the year 1980, Zimbabwe sought to redress a raft of socioeconomic, governance and political challenges. In the main, the biggest challenge lay in the skewed distribution of resources which lay in favour of white people against black Africans. For instance, education was structured such that white learners enjoyed better facilities compared to blacks (Zvobgo, 1986; Shizha \& Kariwo, 2011). A racialised distribution of resources had meant that a small proportion of the population received more resources 
compared to the majority. Unsurprisingly therefore, an expansionary policy was adopted to accommodate as many of the disenfranchised black people as was possible. Education, health and economic development were all attuned to include the black folk. At primary education level, the government adopted universal primary 'Education for All' soon after independence. Health workers from places such as Cuba were recruited as part of the technical support extended to Zimbabwe. Although popular and pro-poor (in the simplest of that term's meaning), the policies of the government proved too strenuous on the economy, leading to budget deficits () and a need for policy retooling. The immediate result was adoption of the Bretton woods-inspired structural adjustment programs which in Zimbabwe was commonly identified as the Economic Structural Adjustment Program (ESAP), lasting from the late 1980s until the mid-1990s. ESAP proved to be a policy nightmare as anticipated gains were not attained and the economy atrophied. ESAP has since been succeeded by a raft of policies, each with its own catchy acronym albeit to the same despairing effect. These include among others the Millennium Economic Recovery Plan (MERP), National Economic Recovery Plan/Programme (NERP) as well as Zimbabwe Agenda for Sustainable Socio-Economic Transformation (ZIMASSET). Importantly in light of the discussion which this paper lays out is the fact that the policies tended to oscillate between external, often Bretton Woods-inspired policies and internal, government-fabricated designs. The state was caught in a vicious circle where both internal and external policies yielded similar outcomes. The verdict remained ambiguous on whose knowledge system was suitable to raise the country out of its economic quagmire.

In agriculture, the most prominent policy advanced in post-independence Zimbabwe has been land reform. The policy is generally divided into two main phases which are (i) the reform programme after 1980 which was based on voluntary transfer through willing-seller, willingbuyer model, as well as (ii) the Fast Track Land Reform Programme (FTLRP) which emerged after a chaotic and violence period of land/farm invasions at the turn of the millennium. All the policies advanced purported to be developmental in nature, that is, to seek the betterment in material terms, of the people of Zimbabwe. However, almost four decades into political independence, the situation is deplorable with rampant unemployment, dilapidated and obsolete infrastructure, widespread poverty and a health system in limbo. Admittedly, there are sections of the farming economy which have achieved positive gains, but these tend to be sparsely situated pockets strewn across the country. Although worthy $\mathrm{f}$ critique on its own, this paper does not dwell on the policies but pays particular attention to the technologies which have been advanced to rival indigenous knowledge; technologies which are deployed as western knowledge. These come in the form of perspectives such as conservation agriculture, resource and wildlife conservancy and farming techniques among others.

\section{SYSTEMS OF KNOWLEDGE AND POWER}

This section deploys a Foucauldian lens to reveal the relationship between knowledge and power. Although Foucault stated that his treatise was not a theory per se, it is still useful in deconstructing knowledge-power dynamics as well as revealing the potentiality of unequal knowledge systems in development theory and practice. A useful starting point in this discussion is Foucault (1982)'s assertion that 'in order to understand what power relations are about, perhaps we should investigate the forms of resistance and attempts made to dissociate these relations' (p.780). This assertion is germane to the Nkayi case and indeed rural Zimbabwe in general where numerous technologies and interventions have been touted and promoted as more useful compared to traditional systems and methods. In assessing the power relations in Zimbabwe, the forms of resistance which came to the fore included blatant sabotage and passive resistance (Baudron, Andersson, Corbeels, \& Giller, 2012). Harnessing on social capital (Bourdieu, Outline of a Theory of Practice, 1977) and resilient networks, 
communities -probably emboldened by the quest for political freedom- engaged in acts of resistance over such technologies as ridge-farming commonly identified as 'makandiwa' and natural resource conservationism (Alexander \& McGregor, 2000).

It must however be noted that forms of resistance deployed by local communities often come as responses to initiatives taken by the state or technical teams. This is suggestive of what development discourse often labels as 'top-down' approaches. In this light, the dispensing of knowledge as power echoes the observation that "power is not a function of consent. In itself it is not a renunciation of freedom, a transference of rights, the power of each and all delegated to a few' (Foucault, 1982, p.788). Knowledge identified in the form of new ideas for agriculture and food preservation falls well within this domain of concentrated power. It is often academics, policymakers, traditional leadership and government apparatchiks who have 'solutions' to help assist rural communities through some 'intervention'. This messianism ignores the reality that the same communities have solutions of their own but may only be constrained by limited resources or indeed little power. The futility of a superhero complex is that it subjects the powerful to the trappings of hubris at the very least or a developmental culde-sac at worst. In the latter case, the agent imposing new technology is trapped in a situation where in order to solve an ever-growing problem, they add more of the same 'solution'. This observation has been made in the area of foreign aid where more aid is offered to assist poor countries (Mavrotas \& Nunnenkamp, 2007) despite the equally harmful effect this may have.

So, if knowledge is a tool through which power held and exercised, how do we understand it? The Foucauldian response would be that an analysis of power is done 'by focusing on carefully defined institutions' (Foucault, 1982, p.791). Institutions in this sense denote 'formal rules, compliance procedures and standard operating procedures that structure relationships between people in various units of the polity or the economy' (Hall \& Taylor, 1986, p7). The discussion which follows will analyse the knowledge systems which contest for development in the rural community of Nkayi. To make a robust, objective analysis, it poses questions consistent with the following schema:

$>$ What is the system of difference

$>$ What are its types of objectives

$>$ What are the means of bringing power relations into being

$>$ What forms of institutionalization does it exhibit

$>$ What are its degrees of rationalization (Foucault, 1982)

\section{METHODOLOGY AND STUDY SITE}

Although relying on data from a case study of Nkayi district, the methodology in this article is not case study in its purest sense. The paper's methodology is based on content analysis of findings from an earlier-conducted study in Nkayi district (see Zikhali, 2017) as well as informal discussions, interviews, observations and transect walks in select wards (15 and 13) of Nkayi. Purposively selected households $(n=38)$ participated in interviews. Having gathered data, the researchers reviewed findings in light of two areas of interest which were sub-issues in earlier studies. The two areas were food preservation and agricultural/farming methods. Some of these issues have been revealed in terms of conservation agriculture uptake $b$ a host of scholars in different fields of specialisation (Mazvimavi \& Twomlow, 2009; Andersson \& Giller, 2012; Baudron, et al., 2012; Ndlovu, et al., 2015; Pedzisa, et al., 2015). To embed the findings within a broader academic discourse, Foucauldian lens have been employed so as to pry open subtle/soft forms of engagement and/or confrontation between local communities and interlopers. 
Nkayi is a district located in western Zimbabwe, in Matabeleland North province which is generally characterised by low average rainfall (see Figure 1 below). The mean annual runoff in Nkayi mirrors that of other dry and arid regions where between 17-70 $\mathrm{mm}$ which translates to river flows especially in Nkayi and Lupane that are seasonal and often dry in the period June to November every year (Hoko, 2005). The political and administrative structure in Zimbabwe follows a hierarchical system where central government is the apex and provincial governments and local governments form the lower tiers. In spite of the differentiated structures, it is central government which distributes and oversees development policy. Local governments are distinct with urban areas comprising of urban authorities and rural local governments defined in the form of rural district councils (RDCs). To better administer their services at local level, the districts are subdivided into wards and these in turn are identified by village. This means that Nkayi district is demarcated into wards (30 in total) which in turn comprise of numerous villages (156 villages) within them (NkayiRDC, n.d.). There is one growth point ${ }^{1}$ in the district which is commonly referred to as Nkayi Business Centre located in Ward 29. According to the 2012 census, the total population in the district amounted to 109, 371 people with an average household size of 5.1 persons (ZimStat, 2011).

By 1988 the major secondary schools in the district were, Hlangabeza High School and Nkayi Secondary School (whose first batch of form four graduands were in 1986-7). In the 1980s, Nkayi Secondary School was servicing a wide area and churning out students who largely emigrated to Bulawayo or across national borders to Botswana and South Africa (Bennell \& Ncube, 1994). The number and distribution of schools has since increased due to various reasons.

\footnotetext{
1 For a look at the growth point development system, see: Tabona-Ncube, G. 2010. Crisis of Communal Leadership: Post-Colonial Local Government Reform and Administrative Conflict with Traditional Authorities in the Communal Areas of Zimbabwe 1980-2008. Zimbabwe Political Science Reviews, 1(1), pp.32-41.
} 


\section{Figure 1: Location of Nkayi District in Zimbabwe Annual Rainfall Distribution}

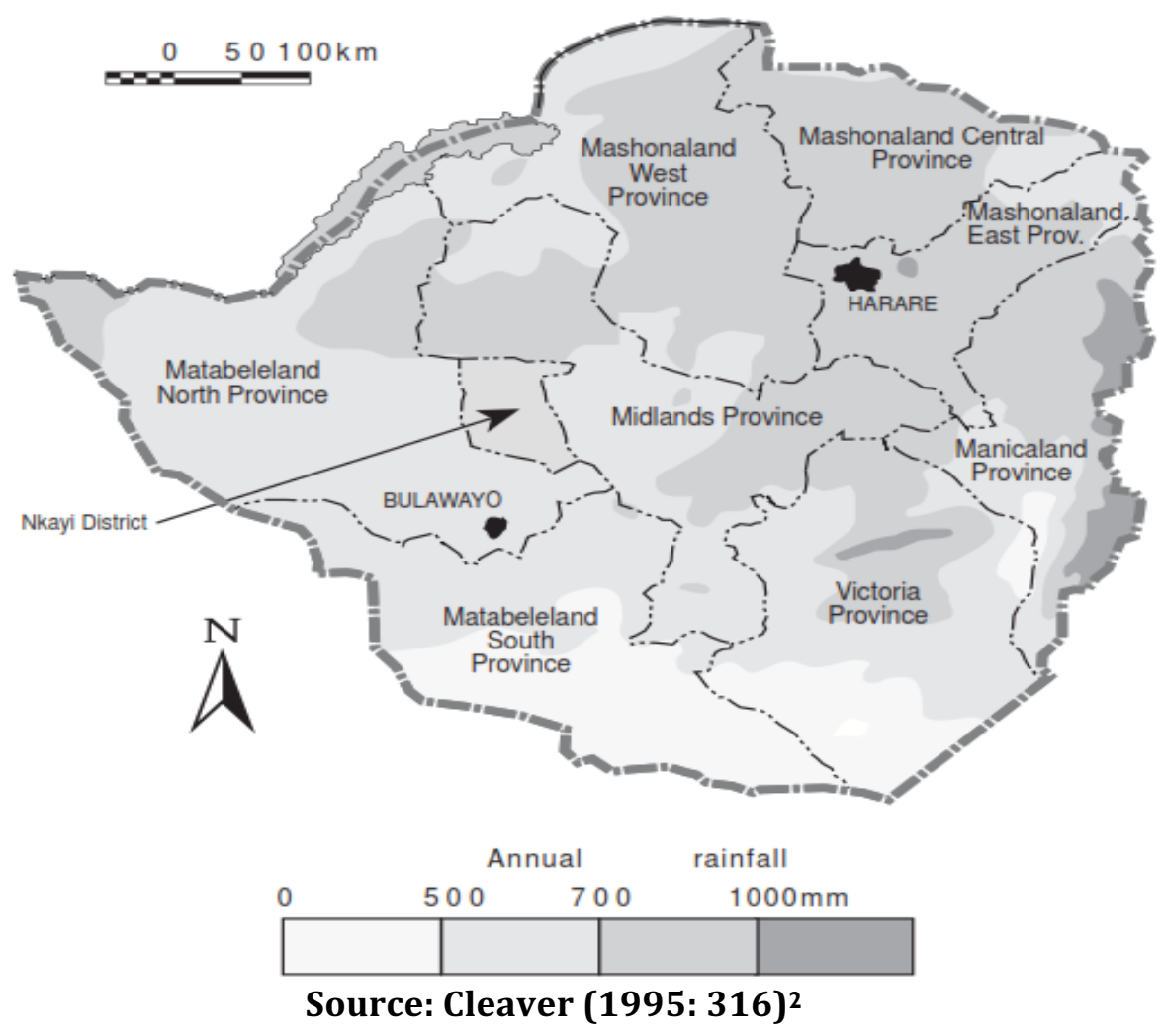

Figure 2 below depicts the demarcation within Nkayi district to reveal wards and boundaries, infrastructure and landmarks within the district.

2 The province marked 'Victoria Province' is actually recognised as Masvingo Province. The name Victoria is a colonial name which has since been discarded in all official platforms. 


\section{Figure 2: Wards in Nkayi District}

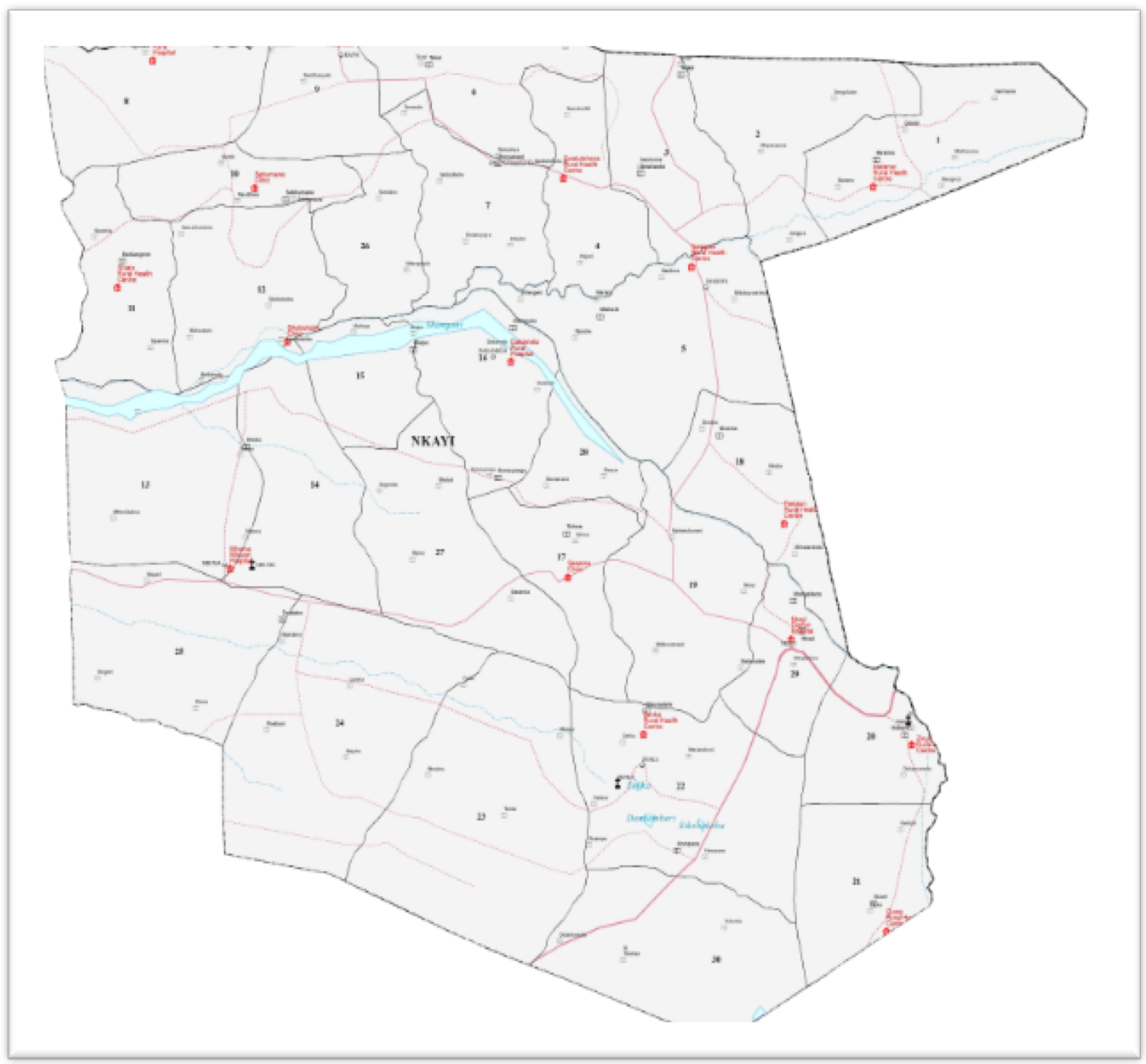

Source: Relief web ${ }^{3}$

\section{NKAYI COMMUNITIES AND SYSTEMS OF KNOWLEDGE: A DEVELOPMENT CONUNDRUM?}

To start off, a tabulated presentation of the study descriptives is laid out. The aim is to reveal the demographics, as well as paint a picture of the household representatives that participated the study.

Table 1: Sample Group Descriptives

\begin{tabular}{|l|l|}
\hline Average age & 56yrs \\
\hline Sex & Male 45\%; Female $=55 \%$ \\
\hline Formal employment status & Employed $=5 \%$; Unemployed $=95 \%$ \\
\hline
\end{tabular}

The descriptive data laid out in Table 1 above relates to the sample participants who took part in interviews. Of importance is the fact that the participants are strictly household heads. Given the migration patterns in the area and in Zimbabwe in general, it is hardly surprising that the 
average age is high and the greater proportion are females. The general pattern is that men emigrate more than women and it is wives who remain behind to care for the family. The balanced distribution may however be suggestive of a shift in this pattern.

There are two main areas which are of interest in this paper regarding knowledge systems. To recap, the main concern is to analyse systems of knowledge - in this case western and indigenous- using the case of Nkayi communities. While there are various ways such analyses could be made, the paper focuses on food preservation and agricultural/farming approaches. In this vein, the focus was on preservation methods in food stored both in the short term as well as in the long term. In addition, the farming techniques employed in the fields were investigated and contrasted with the approaches advanced through various initiatives. The table below lists the food preservation methods employed by indigenous groups in presentday Matabeleland north and specifically in Nkayi district. The most common methods of preserving food identified were classified either as drying fresh produce, boiling and drying it, storing it in granaries or storing it in safe storage facilities. In addition to preservation, there are also a number of techniques which were used as ingenious farming methods. The idea of identifying these approaches is merely to portray a snapshot of the approaches and not to present an exhaustive list of approaches.

\begin{tabular}{|c|c|c|}
\hline METHOD & $\begin{array}{l}\text { FOOD } \\
\text { ITEM/FACILITY }\end{array}$ & NDEBELE TERM \\
\hline \multirow[t]{2}{*}{ DRYING } & Biltong & imihwabha or imibengo \\
\hline & Sweet reed stalks & Umhlutshwa \\
\hline BOILING & $\begin{array}{l}\text { Boiled and dried } \\
\text { maize }\end{array}$ & \\
\hline OTHER PROCESSING & Sour milk & amasi \\
\hline \multirow[t]{3}{*}{ STORAGE } & Safe storage & umncantsha \\
\hline & Granaries & ezilulwini \\
\hline & Kitchen & \\
\hline
\end{tabular}

Table 2 above reveals the various food items and facilities which are used in the preservation of food items in Nkayi. While most of the methods appear readily discernible, it must be noted that the storage facilities tended to rely on savvy knowledge of natural repellants and appropriate controls. For example, granaries and kitchens were made of mud and this was coated in cow manure. The manure served as a repellant to parasites and bugs while the mud layer allowed for cool dry environments. The result was a storage facility attuned to the desired conditions for grain storage. The kitchen also plays a useful role in that it is often characterized by smoke from burning firewood. Such smoke serves as an added repellant to bugs and parasites. In addition to identifying the methods for preservation, it is important to recognize the gendered roles which played out. Men generally do not participate in food preparation and preservation. Their job is done once they have harvested or slaughtered an animal. Even then, the type of animal to be slaughtered and later preserved -if need be- is slaughtered on gendered lines. Chickens can be slaughtered by females but goats, cattle and pigs are almost exclusively slaughtered by men. It is only in the food preparation and preservation that women enter the fray. This scenario is analyzed in the following section which ties conceptual issues to the findings from Nkyai.

In addition to the above indicated food preservation techniques, there also exist a plethora of farming methods which indigenous groups resorted to. Farming in this study refers to the 
entire spectrum of on-farm productive activities which rural communities engage in within the realm of agriculture. This suggests that animal husbandry as well as crop production were considered. Numerous indigenous approaches were observed. For example, despite cautions against farming on wetlands, careful farming of select crops near wetlands was practiced. This approach is consistent with traditional approaches identified by Mapara (2009) in his discussion of indigenous knowledge systems as postcolonial epistemes. Furthermore, grazing lands were selectively used -often on rotational basis following communally agreed patternsfor cattle and other grazing livestock.

Having identified these approaches, the question then is, what of western forms of knowledge? In essence, the approaches follow similar flows as drying and safe storage are deployed. However, a key element is that there is extensive use of preservatives and chemicals to protect food (especially grains) from spoilage as a result of bugs. Hence numerous branded chemicals and preservative dusts are on offer to farmers. In contrast to this, western agricultural methods are extensive, rely on equipment and more importantly, employ open tillage when carried out as the common farming method in Zimbabwe or rely on conservation agriculture principles -when used as conservation agriculture proponents would suggest. In fact, while grains were often stored and selected for planting in the next season, reliance on commercially-available treated varieties has resulted in such practices ebbing away. The table below shows the responses to the question 'do you keep your main crop's seed for replanting in the next season?'.

Table 3: Do you keep your main crop's seed for replanting in the next season? $(n=38)$

\begin{tabular}{|l|l|}
\hline Yes & No \\
\hline $34 \%$ & $66 \%$ \\
\hline
\end{tabular}

Although useful in identifying the households which rely on stored seed, it is important to flag the limitation to a primary crop which in this case was maize. Many other crops are grown by farmers in Nkayi such as groundnuts, roundnuts, millet and so forth. Such crops generally tend to be grown from the stock of stored seeds as evidenced by the results in Table 3 below.

Table 4: Do you use stored seeds for planting in other crops?

\begin{tabular}{|l|l|l|}
\hline Crop & Yes & No \\
\hline Millet & $45 \%$ & $55 \%$ \\
\hline Sorghum & $40 \%$ & $60 \%$ \\
\hline Groundnuts & $60 \%$ & $40 \%$ \\
\hline Roundnuts & $66 \%$ & $34 \%$ \\
\hline Barley & $63 \%$ & $37 \%$ \\
\hline
\end{tabular}

Table 4 above reveals that crops which are not staples yet are grown in the rural communities studied are planted from stored grain much more compared to maize. It is important to recognize that these crops are traditionally important in the diet of these ethnic groups in Zimbabwe.

A striking observation which the researchers made was that although knowledge systems were contrasted for the sake of academic distinction, in practical terms communities and households in Nkayi often used both sytems in tandem. For instance, grain was treated using some chemical compounds purchased from agro-supplies shops. It however would be stored in granaries which were built in keeping with traditional methods. The granaries were mostly made of mud, would be coated in cow dung and were on surfaces which were impermeable especially by water. In addition, some members indicated that they solicited guidance and 
advice from agricultural extension officers even in matters relating to indigenous farming practices. The irony is that while academics and policymakers appear to split the systems of knowledge, those persons in contact at the level of practice find ways to collaborate.

\section{ASSESSING THE KNOWLEDGE SYSTEMS}

Having identified the common techniques and approaches in both western and indigenous knowledge systems, it is important to situate them within the conceptual and analytical frames outlined earlier. In short, knowledge systems have been identified as bodies of power. In this vein, they bring together academics, trainers, extension officers, chiefs, leaders, local communities, indigenous groups, values and so forth. In the context of our discussion, the various actors represent and conform to or are disposed to promote a given system of knowledge more than they do another. This disequilibrium informs ${ }^{4}$ a people's outlook, their notions of progress and development. The element of power is manifest through what Foucault (1982) identifies as 'pastoral power'. Here, there are premiums placed on various forms of knowledge such that it is deemed that in one group, knowledge is a source of capital while in another it is a liability. Indigenous knowledge has for long been confined to the latter where it is deemed 'unscientific' and not objectively verified. This empiricist and colonialist stance has been revised as has been laid out in the introduction. In Nkayi, the study has observed that although technocrats produce 'solutions' and technologies, packaged in policy documents and scientific papers, communities still maintain practices steeped in tradition and culture. For them, development is not exclusively derived from what the scientists declare but from a fusion of approaches. It is in this sense that while technocrats, development workers and so forth are powerful due to their position as a form of pastorate, they still have to negotiate 'buyin' from rural communities.

Instead of adopting a historically grounded analysis as Foucault did, we point out the key elements in the knowledge-power dynamic and how it plays out in Nkayi in light of four earlier-identified questions which are:

$>$ What is the system of difference

$>$ What are its types of objectives

$>$ What are the means of bringing power relations into being

$>$ What forms of institutionalization does it exhibit

$>$ What are its degrees of rationalization (Foucault, 1982)

To pool together a response addressing all four questions, the difference between western and indigenous knowledge systems in Nkayi is that the former is intertwined with western values, systems of thought and insights based on different systems while the latter is fashioned around dynamic local culture. Both are crafted in the interest of progress in various forms. In our discussion, progress may mean more reliable preservation methods, better yields or greater productivity. A layered structure is employed in western knowledge where scientists produce knowledge after conducting experiments and such techniques. In contrast, in IKS, often gendered roles and political rank define positions of power. The forms and level of institutionalization also differ. Western knowledge systems are largely formally coded, have clearly defined systems and ethics. On the other hand, IKS relies on loose institutions which are flexible to the dictates of the environment. Given the contrasts and very few similarities as well as the logics and rationale employed, it is little surprise that the two systems have different grades of rationalization. To know in western systems is a quality attained through rigorous processes and checks and balances. This of course does not apply in the case of political actors

${ }^{4}$ Here we have utilized the term 'informs' advisedly because no causality can be claimed from our findings. 
or some community leaders in Nkayi such as local politicians and businesspeople. Instead, it is a rationalization confined to those who have attained high levels of education. IKSs on the other hand are broader albeit with gendered restrictions. No formal qualification is required and therefore knowledge is readily accessible in fields such as agriculture and food preservation. A caveat suffices here, IKS can be very restrictive when the knowledge base is in other fields such as medicine production.

Given the aforementioned, what lessons can we derive from the households considered in Nkayi? Power and the knowledge that is attached to it are derived from multiple sources which include gendered differentiation, bases of knowledge and stature. in other words, those with knowledge-derived power have attained it through their gendered roles, through the forms of knowledge which they acquire or through their status in the socio-political public. In addition, power is not a given but tends to be negotiated as is evidenced by the dual deployment of western and indigenous knowledge. History has revealed that western solutions in rural areas have struggled due to resistance and rejection or apathetic uptake. Indigenous knowledge has not stayed true and unscathed over the same period. As a result, some communities now cherry-pick elements on either side to better respond to their present-day realities. In spite of these negotiations and strategies, the perceptions that some knowledge systems have more credibility than others remain embedded in the approaches portrayed as development solutions and projects of some agencies.

\section{CONCLUSION}

The study has discussed the knowledge-power dynamic inherent in knowledge systems. To engage in such an exercise, the paper laid out contrasts and comparisons of western knowledge and IKS using findings from Nkayi in Zimbabwe. Identifying the scope for comparison or contrast was not sufficient due to the fact that a conceptual frame was required. Foucault's notion of 'pastoral power' and his understanding of how knowledge and power relate were used. The starting point was to recognise that with regards to such systems as IKS, knowledge is power (Sibanda, 1998) and that 'in order to understand what power relations are about, perhaps we should investigate the forms of resistance and attempts made to dissociate these relations' (Foucault, 1982, p.780). western knowledge was therefore contrasted with IKS with examples drawn from such practices as conservation agriculture. It is clear however, that knowledge and therefore power are not zero-sum games with outright winners and outright losers. Instead, communities use both systems to better respond to their challenges and needs. IKS and western systems can be mutually effective creating new possibilities for envisioning development. As a result, there are conceptual and practical lessons to be derived which are laid out here in the form of recommendations.

Development policymakers and practitioners are urged to consider the power relations which prevail between 'suppliers' of development and those to whom development interventions are extended. Instead of construing negotiations as resistance and deficient 'buy-in', there is need to reframe the perspective and see communities as reservoirs of knowledge and independent development agents equally equipped with the skills and interests to fashion their own versions of development. After all, if development is freedom (Sen, 1999), then is it not fitting that communities are free to chose which solutions are best suited to their reality instead of gorging standardised solutions? In considering and allowing for negotiations, a more inclusive approach to development interventions is adopted. The irony here is that such recommendations continue to be sounded in Zimbabwe four decades after top-down technologies were imposed on ruralfolk by a colonial system guided by its own modernisation agenda. 
There is real conceptual value in considering the power dynamics outlined here. This is particularly relevant to academics. What do we mean when terms and neologisms are fashioned and pasted onto those in rural communities as though they do not have agency to define who they are and what they represent. These 'buzzwords and fuzzwords' are not produced by the rural folk. Instead, they are churned out in academic papers, symposia, lecture rooms and elitist discussion panels. The point here is that those wielding power to label, to define and to elaborate do so with little regard for what identities the other crafts for him/herself. The folly of such a position is that it may miss the domains of power which peasants/ruralfolk and the subaltern in general have. Worse still is that it may miss out on opportunities for collaboration as one group becomes enamoured in their hubris, believing in a false scientific omniscience while ignoring the reservoirs of knowledge "out there". Academics and development thinkers ought to collaborate with the poor to identify a common language which devolves the power inherent in language and in knowledge so that better solutions are crafted. What is known becomes a shared resource instead of one confined to objective science or indigenous knowledge systems alone. The net effect here is that systems of knowledge will not be pitted as direct opposites but construed as complementary forces intended to attain a common objective.

\section{References}

Alexander, J. \& McGregor, J., 2000. Wildlife and politics: Campfire in Zimbabwe. Development and Change, 31(3), pp. 605-627.

Andersson, J. A. \& Giller, K. E., 2012. On heretics and God's blanket salesmen: contested claims for Conservation Agriculture and the politics of its promotion in African smallholder farming. In: J. Sumberg \& J. Thompson, eds. Contested Agronomy: Agricultural Research in a Changing World. London: Earthscan, pp. 1-22.

Baudron, F., Andersson, J. A., Corbeels, M. \& Giller, K. E., 2012. Failing to Yield? Ploughs, Conservation Agriculture and the Problem of Agricultural Intensification: An Example from the Zambezi Valley, Zimbabwe. Journal of Development Studies, p. 393-412.

Bennell, P. \& Ncube, M., 1994. Jobs for the Boys? The Employment Experiences of Secondary School-Leavers in Zimbabwe. Journal of Southern African Studies, 20(2), pp. 301-316.

Bourdieu, P., 1977. Outline of a Theory of Practice. Cambridge: Press Syndicate of the University of Cambridge.

Bourdieu, P., 1991. Language and Symbolic Power. Oxford: Polity Press.

Brett, E. A., 2005. From Corporatism to Liberalisation in Zimbabwe: Economic Policy Regimes and Political Crisis (1980-1997), London: Crisis States Research Centre and London School of Economics.

Chambers, R., 1983. Rural Development: Putting the last first. 1st ed. London: Longman.

Coltart, D., 2008. A Decade of Suffering in Zimbabwe: Economic Collapse and Political Repression under Robert Mugabe, Washington: CATO Institute.

Cornwall, A., 2007. Buzzwords and Fuzzwords: Deconstructing Development Discourse. Development in Practise, 17(4/5), pp. 471-484.

Foucault, M., 1982. The subject and power. Critical Enquiry, Volume 8, pp. 777-795.

Hall, P. A. \& Taylor, R. C. R., 1986. Political Science and the Three New Institutionalisms. Political Studies, Volume 64, pp. 936-957.

Hoko, Z., 2005. An assessment of the water quality of drinking water in rural districts in Zimbabwe. The case of Gokwe South, Nkayi, Lupane, and Mwenezi districts. Physics and Chemistry of the Earth, Volume 30, p. 859-866 doi: 10.1016/j.pce.2005.08.031.

Mapara, J. 2009. Indigenous Knowledge Systems in Zimbabwe: Juxtaposing postcolonial theory. The Journal of Pan African Studies, 3(1), pp.139-155.

Mavrotas, G. \& Nunnenkamp, P., 2007. Foreign Aid Heterogeneity: Issues and Agenda. Review of World Economics / Weltwirtschaftliches Archiv, 143(4), pp. 585-595.

Mazvimavi, K. \& Twomlow, S., 2009. Socioeconomic and institutional factors influencing adoption of conservation farming by vulnerable households in Zimbabwe. Agricultural Systems, Volume.101, p. 20-29. 
Ndlovu, T., Moyo, F., Zikhali, W. \& Mabhena, C., 2015. Farmer participation: a drive towards sustainable agricultural production in Makwe irrigation scheme, Zimbabwe. Global Journal of Agricultural Economics, Extension and Rural Development, pp. 308-320.

NkayiRDC, n.d. Nkayi Rural District Council. [Online] Available at: http://nkayirdc.co.zw/index.php/aboutus/nkayi-rural-district-council.html

[Accessed 04 July 2017].

Pedzisa, T. et al., 2015. Abandonment of Conservation Agriculture by Smallholder Farmers in Zimbabwe. Journal of Sustainable Development, pp. 69-82.

Rainbow, P., 1984. The Foucault Reader. 1st ed. New York: Pantheon Books.

Shizha, E. \& Kariwo, M. T., 2011. Education and Development in Zimbabwe: A Social, Political and Economic Analysis. Rotterdam: Sense Publishers.

Sibanda, H. 1998. Sustainable Indigenous Knowledge Systems In Agriculture in Zimbabwe's Rural Areas of Matabeleland North and South Provinces: Zimbabwe case study. New York: World Bank accessed from: https://openknowledge.worldbank.org/bitstream/handle/10986/10836/multi_page.pdf?sequence=1\&isAllowed $=\mathrm{y}$

Spivak, G. C., 1987. In Other Worlds: Essays in Cultural Politics. 1st ed. New York: Methuen.

UNESCO, 2017, Local and Indigenous Knowledge Systems," United Nations Educational, Scientific, and Cultural Organization, accessed on July 16, 2017, http://www.unesco.org/new/en/natural-sciences/priorityareas/links/relatedinformation/what-is-local-and-indigenous-knowledge/.

Zikhali, W. 2017. An evaluation of conservation farming as a drive towards sustainable agricultural production at Sivomo area, Nkayi district, Zimbabwe. IASET: International Journal of Agricultural \& Bio-Chemical Science,1(1), pp.17-32.

ZimStat, 2011. Census 2012: Preliminary Report, Harare: Zimbabwe National Statistics Agency.

Zvobgo, R., 1986. Education and the Chalenge of Independence. In: I. Mandaza, ed. The Political Economy of Transition 1980-1986. Dakar: CODESRIA, pp. 319-354. 